\title{
Numerical Classification of Thermophilic Streptomycetes
}

\author{
By M. GOODFELLOW,${ }^{*}$ J. LACEY ${ }^{2}$ AND CAROLE TODD ${ }^{1}$ \\ 'Department of Microbiology, The Medical School, Framlington Place, \\ Newcastle upon Tyne NE2 $4 H H, U K$ \\ ${ }^{2}$ Plant Pathology Department, Rothamsted Experimental Station, Harpenden, \\ Herts AL5 2JQ, UK
}

(Received 19 March 1987; revised 25 June 1987)

\begin{abstract}
Fifty thermophilic streptomycetes from diverse habitats were compared through 135 unit characters with 201 representative mesophilic streptomycetes from an earlier numerical phenetic study. Data were examined using the simple matching $\left(S_{\mathrm{SM}}\right)$, Jaccard $\left(S_{\mathrm{J}}\right)$ and pattern $\left(D_{\mathrm{P}}\right)$ coefficients, and clustering was achieved using the unweighted pair group method with arithmetic averages (UPGMA) technique. In all three analyses, the thermophilic streptomycetes formed an aggregate taxon composed of three major (seven to nineteen strains), five minor (two to three strains) and two single-member clusters. Cluster composition was not affected by the statistics used. The numerical phenetic data showed that thermophilic streptomycetes form several distinct centres of variation, four of which correspond to previously described species; a further taxon was also considered to merit species status. It is proposed that Streptomyces thermolineatus sp. nov. be recognized and the name Streptomyces macrosporus Krassilnikov et al. 1968 be revived. Emended descriptions are given for Streptomyces megasporus (Krassilnikov et al., 1968) Agre 1983, Streptomyces thermoviolaceus Henssen 1957 and Streptomyces thermovulgaris Henssen 1957.
\end{abstract}

\section{INTRODUCTION}

Thermophilic streptomycetes have received little attention from taxonomists despite their potential importance in microbial technology (Kutzner, 1981). Streptomyces thermodiastaticus (Bergey et al., 1923) Waksman 1953, Streptomyces thermonitrificans Desai \& Dhala 1967, Streptomyces thermoviolaceus Henssen 1957 and Streptomyces thermovulgaris Henssen 1957 are cited in the Approved Lists of Bacterial Names (Skerman et al., 1980) and Streptomyces megasporus (Krassilnikov et al., 1968) and Streptomyces glaucosporus (Krassilnikov et al., 1968), have recently been revived and validated (Agre, 1983, 1986) but 'Streptomyces macrosporus' (Krassilnikov et al., 1968), 'Streptomyces thermoflavus' (Kudrina \& Maksimova, 1963) Pridham 1970, 'Streptomyces thermofuscus' (Waksman et al., 1939) Waksman \& Henrici 1948, 'Streptomyces thermophilus' (Gilbert, 1904) Waksman \& Henrici 1948 (syn. Streptomyces rectus; Henssen, 1957) or the illegitimately described 'Streptomyces thermotolerans' are not listed in the Approved Lists and have not been validly published since 1 January 1980.

Thermophilic streptomycetes have growth temperature ranges between $28^{\circ} \mathrm{C}$ and $55^{\circ} \mathrm{C}$, although cultures of 'S. thermofuscus' and 'S. thermophilus' have been reported to grow at $65^{\circ} \mathrm{C}$ (Waksman et al., 1939). It is a matter of some controversy whether streptomycetes that grow at or above $45^{\circ} \mathrm{C}$ should be assigned to distinct taxa or whether they should be considered only as thermotolerant variants of mesophilic species. Craveri \& Pagani (1962) proposed the subgenus Thermostreptomyces for thermophilic taxa but other workers (Corbaz et al., 1963; Küster \& Locci, 1963) regarded such organisms as thermotolerant rather than thermophilic. The name Thermostreptomyces was listed under genera incertae sedis in the eighth edition of Bergey's Manual of Determinative Bacteriology (Pridham \& Tresner, 1974). 
Table 1. Description and source of thermophilic strains assigned to clusters in the $S_{\mathrm{SM}}$, UPGMA analysis

Strain no.

\section{${ }^{*} \mathrm{~K} 27$}

$\mathrm{K} 1, \mathrm{~K} 2, \mathrm{~K} 5$

$\mathrm{K} 3, \mathrm{~K} 4, \mathrm{~K} 8-\mathrm{K} 10$, $\mathrm{K} 13, \mathrm{~K} 14, \mathrm{~K} 16$

K 11

K31

K34

K35

K40

$\mathrm{K} 41$

$\mathrm{K} 42$

${ }^{*} \mathrm{~K} 25$

${ }^{*} \mathrm{~K} 26$

K22

K33

K32

K23

K24

$\mathrm{K} 6, \mathrm{~K} 18$

K12

K28-K30

K19

*K44

K20

K38, K39

K43

K46

K48-K 50

${ }^{*} \mathrm{~K} 45$

K 21, K47

K7, K 15, K 17

K37

K36

Name as received $\dagger$

Source history

(a) Strains assigned to cluster 1 (Streptomyces thermovulgaris)

\section{S. thermovulgaris}

Streptomyces sp.

Streptomyces sp.

Streptomyces sp.

Streptomyces sp.

Streptomyces sp.

Streptomyces sp.

Streptomyces sp.

Streptomyces sp.

Streptomyces sp.
A. Seino, KCC S-0520; T. Hasegawa, IFO 13089; SAJ;

E. B. Shirling, ISP 5444; A. Henssen, MB R 10

C. Todd, garden compost $\mathrm{C} 1$, Newcastle upon Tyne

C. Todd, garden compost $\mathrm{C} 2$, Newcastle upon Tyne

C. Todd, mushroom compost, UK

C. Lyons, Department of Microbiology, The University, Newcastle upon Tyne, CL4, garden compost

J. Lacey, A372; bagasse, Jamaica

J. Lacey, A563; bagasse, Trinidad

J. Lacey, A902; coffee dust, Trinidad

J. Lacey, A928; mushroom compost, UK

J. Lacey, A956; cocoa beans, Trinidad

(b) Strains assigned to cluster 2 (Streptomyces thermoviolaceus)

'S. thermoflavus'

S. thermonitrificans

S. thermoviolaceus

$S$. thermoviolaceus

$S$. thermoviolaceus subsp. apingens

$S$. thermoviolaceus subsp. thermoviolaceus

$S$. thermoviolaceus subsp. thermoviolaceus
A. Seino, KCC S-0135 (ISP 5574); T. Cross, CUB 75; NCIB 9670; N. Okafor; rotting maize, Ado-Ekiti, Nigeria

A. Seino, KCC S-0841; IFO 13473; SAJ; ISP 5579; ATCC 23385; A. J. Desai, NCIMB 2007; soil, Bombay, India

J. Lacey, CD183; grain dust, Canada

J. Lacey, A74; hay, Devon, UK

J. Lacey, A71; hay, Rothamsted, Harpenden, UK

J. Lacey, A221; bagasse, Trinidad

J. Lacey, A74; hay, Rothamsted, UK

(c) Strains assigned to cluster 3 (Streptomyces $\mathrm{sp}$.)
Streptomyces sp.
C. Todd, garden compost C2
Streptomyces sp.
C. Todd, garden compost $\mathrm{Cl}$

(d) Strains assigned to cluster 4 (Streptomyces sp.)
Streptomyces sp.
C. Lyons, CL1, CL2, CL3; garden compost

(e) Strains assigned to cluster 5 (Streptomyces macrosporus)
'S. macrosporus'
J. Lacey, A1488; sewage compost, USA
'S. macrosporus'
J. Lacey, A1201; N. S. Agre, 2892

(f) Strains assigned to cluster 6 (Streptomyces megasporus)
'S. macrosporus'
J. Lacey, A1489; sewage compost, USA

'S. macrosporus'

J. Lacey, A848, A849; air, hayfield, Rothamsted, Harpenden, UK

'S. macrosporus'

'S. macrosporus'

J. Lacey, A1062; mushroom compost, Suffolk, UK

'S. macrosporus'

J. Lacey, A1362; air, cotton mill, Lancashire, UK

S. megasporus

J. Lacey, A1485, A1486, A1487; sewage compost, USA

J. Lacey, A1202; N. S. Agre, 1869

(g) Strains assigned to cluster 7 (Streptomyces thermolineatus)

'S. macrosporus'

J. Lacey, A1601, A1484; sewage compost, USA

(h) Strains assigned to cluster 8 (Streptomyces albus)

Streptomyces sp.

C. Todd, garden compost $\mathrm{Cl}$

(i) Single member clusters

Streptomyces sp.

Streptomyces sp.
J. Lacey, A600; barley grain, Cambridge, UK

J. Lacey, A592; bagasse, USA 
Williams et al. (1983) made an extensive numerical phenetic survey of the type strains of Streptomyces species in which 'S. thermoflavus' ISP 5574, S. thermonitrificans ISP 5579 and $S$. thermovulgaris ISP 5444 were recovered in a single cluster and four other strains considered to be thermophilic (received as $S$. thermodiastaticus, 'S. thermophilus', 'S. thermotolerans' and $S$. thermoviolaceus) were assigned to the periphery of numerically defined groups containing mesophilic strains. Thus, $S$. thermodiastaticus ISP 5573 was recovered in subcluster $1 \mathrm{C}$ ( $S$. halstedii), 'S. thermophilus' ISP 5365 (S. rectus) in cluster 15 (S. chromofuscus), 'S. thermotolerans' ISP 5227 in cluster 18 (S. cyaneus) and $S$. thermoviolaceus ISP 5443 in cluster 45 ( $S$. aurantiacus).

The primary aim of the present study was to clarify the taxonomy of thermophilic streptomycetes by comparing phenetic data from representative strains with corresponding results obtained on marker mesophilic strains examined by Williams et al. (1983). The two data sets were compared using standard numerical taxonomic techniques.

\section{METHODS}

Isolation of thermophilic streptomycetes. Two samples of garden compost, and one of mushroom compost, were incubated at $55^{\circ} \mathrm{C}$ for $7 \mathrm{~d}$. Preincubated samples ( $\mathrm{g}$ each) were shaken separately in $10 \mathrm{ml}$ of quarter-strength Ringer's Solution (Oxoid, BR52) on a Griffin flask shaker (Griffin \& George) at speed setting 8 for 30 min. Samples $(0 \cdot 2 \mathrm{ml})$ of $10^{-2}$ to $10^{5}$ serial, logarithmic dilutions were spread over the surface of starch-casein nitrate agar plates (Küster \& Williams, 1964) supplemented with actidione $\left(50 \mu \mathrm{g} \mathrm{ml}^{-1}\right.$; Sigma) and rifampicin $(0.5 \mu \mathrm{g}$ $\mathrm{ml}^{-1}$; Sigma) (five plates per dilution) and incubated at $55^{\circ} \mathrm{C}$ for $7 \mathrm{~d}$. Streptomycete counts were expressed as numbers of colony-forming units (c.f.u.) ( $\mathrm{g}$ dry wt of sample) ${ }^{-1}$; dry weights were obtained at $105^{\circ} \mathrm{C}$. Eighteen randomly selected isolates with the colony appearance and morphology of streptomycetes, from isolation plates with 30-100 colonies, were subcultured on starch-casein nitrate agar plates, incubated at $45^{\circ} \mathrm{C}$ for $5 \mathrm{~d}$ and checked for purity by microscopic examination of Gram-stained smears. Other isolates were obtained from samples of mouldy hay, sugar-cane bagasse, cereal grain, coffee dust, cocoa beans, mushroom compost, and from a sewage compost using an Andersen sampler/wind tunnel method (Gregory \& Lacey, 1963; Lacey \& Dutkiewicz, 1976) or from air over pastures and in a cotton mill using an Andersen sampler (Lacey, 1975; Lacey \& Lacey, 1987).

Fifty thermophilic strains comprising 45 isolates together with the type strains of five Streptomyces species were examined (Table 1). Strains were maintained on modified Bennett's agar slopes (Jones, 1949) at $4{ }^{\circ} \mathrm{C}$ and as suspensions of spores or mycelial fragments in glycerol $(20 \%, \mathrm{v} / \mathrm{v})$ at $-25^{\circ} \mathrm{C}$ (Wellington \& Williams, 1978).

Collection of data. Cultures were examined using all but four of the tests described by Williams et al. (1983); strains were not tested for xylan degradation, Klebsiella $\beta$-lactamase inhibitor or $\beta$-lactamase production on YPG or Beecham's FS agars. The test regimes of Williams et al. (1983) were followed except that, apart from measuring growth temperature requirements, all tests were incubated at $45^{\circ} \mathrm{C}$ and read after 3 and $7 \mathrm{~d}$. The final test readings were used to provide data for computation. Tests were repeated only when ambiguous or clearly unexpected results were obtained. The data were added to the corresponding results obtained with the streptomycetes assigned to the major and minor clusters recovered by Williams et al. (1983). The final data matrix contained 251 strains and 135 unit characters.

Coding of data. Nearly all of the characters existed in one of two mutually exclusive states and were scored plus (1) or minus (0). Qualitative multistate characters, such as pigmentation and spore-chain morphology, were coded as several independent characters scored plus (1) for the character state shown and minus (0) for all alternatives. Quantitative multistate characters, such as tolerance to chemical inhibitors, were scored using the additive method of Sneath \& Sokal (1973).

Computation. Data were examined using the Clustan 1C program (Wishart, 1978) on an IBM 370/180 computer, using the simple matching coefficient $\left(S_{\mathrm{SM}}\right.$; Sokal \& Michener, 1958), which includes both positive and negative similarities, the Jaccard coefficient $\left(S_{\mathrm{J}}\right.$; Sneath, 1957), which includes positive matches only, and the pattern coefficient $\left(D_{\mathrm{P}} ;\right.$ Wishart, 1978), which allows for differences in growth rates, periods of incubation and similar

* Type strain.

† Binomials in inverted commas were not included in the Approved Lists of Bacterial Names (Skerman et al., 1980 ) and have not been validly published since January 1980.

$\$$ KCC, Culture Collection of Actinomycetes, Kaken Chemical Co. Ltd, 6-42 Jujodai 1-chome, Kita-ku, Tokyo 114, Japan; IFO, Institute for Fermentation, Yodogawa-ku, Osaka, Japan; SAJ, Society for Actinomycetes, Tokyo, Japan; ISP, International Streptomyces Project reference number; CUB, Culture Collection, University of Bradford, Yorkshire, UK; NCIB, National Collection of Industrial Bacteria, Torry Research Institute, Aberdeen. 
factors that can distort similarity values (Sneath, 1968). Clustering was achieved using the unweighted pair group method with averages (UPGMA) algorithm (Sneath \& Sokal, 1973).

Morphological studies. Additional morphological data on isolates were obtained using half-strength nutrient and V-8 juice agars (Corbaz et al., 1963) and ISP media (Shirling \& Gottlieb, 1966). Cultures were incubated at 25 and $40{ }^{\circ} \mathrm{C}$ and examined in situ on the agar surface using a compound microscope equipped with $\times 20$ and $\times 40$ objectives. The colour series of the spore mass was determined by comparison with standard colour tabs as described by Tresner \& Backus (1963).

Spores, collected by touching collodion-coated copper grids onto sporulating cultures, were examined without further treatment using a Siemens Elmiskop 1A transmission electron microscope. For scanning electron microscopy, spores were mounted on stubs using double-sided adhesive tape and coated with gold before examination in a Hitachi 5450 scanning electron microscope.

\section{RESULTS}

The garden compost samples $\mathrm{C} 1$ and $\mathrm{C} 2$ contained $4.9-5.0 \times 10^{5}$ c.f.u. of thermophilic streptomycetes (g dry wt of sample) $)^{-1}$ and the mushroom compost $10^{3}$ c.f.u. (g dry wt $)^{-1}$. The thermophilic streptomycete content of other samples differed with storage conditions, most being found in mouldy hay and sugar-cane bagasse after spontaneous heating to $>50^{\circ} \mathrm{C}$, when grey thermophilic Streptomyces numbered up to $10^{5} \mathrm{~g}^{-1}$ and $S$. albus up to $10^{7} \mathrm{~g}^{-1}$. Other species isolated included Thermoactinomyces species, Faenia rectivirgula and Saccharomonospora viridis.

\section{Numerical classification}

The thermophilic streptomycetes formed a distinct aggregate cluster. All the remaining strains were placed in the major and minor clusters recognized by Williams et al. (1983) and, with the exception of $S$. albus, formed a separate aggregate cluster. The mesophilic streptomycetes have not, therefore, been considered further.

The classification based on the $S_{\mathrm{SM}}$, UPGMA analysis is described in detail as it gave the most compact clusters. The 50 test isolates were recovered in three major (seven to nineteen strains), five minor (two to three strains) and two single-member clusters at the $82 \%$ similarity $(S)$-level (Fig. 1). Where possible, clusters were named after the earliest described species that they contained.

Cluster 1 was the largest and was defined just below the $90 \% S$-level. It contained the type strain of $S$. thermovulgaris and 18 other strains from different habitats (see Table 1). Cluster 1 showed a close similarity $(>80 \%$ ) to cluster 2 , which was also homogeneous and circumscribed just above the $90 \% S$-level. In addition to isolates received as $S$. thermoviolaceus, cluster 2 contained type and reference strains of $S$. thermonitrificans and ' $S$. thermoflavus', respectively. The third major cluster, cluster 6 , was defined at the $84 \% S$-level. It included the type strain of $S$. megasporus and eight other isolates from air and composts. The type strain of ' $S$. macrosporus' formed minor cluster 5 with one other isolate from compost. The remaining clusters did not contain marker strains and were labelled Streptomyces sp. Clusters 3, 4 and 8 each contained three isolates from garden compost and cluster 7 contained duplicate strains from sewage compost; two other isolates were recovered as single-member clusters. The cluster 8 strains were classified as $S$. albus as they were closely associated with cluster 16 of Williams et al. (1983), which contained the type strain of $S$. albus and two other strains which had all been cultivated at $25{ }^{\circ} \mathrm{C}$.

The same clusters were recovered in the $S_{\mathrm{J}}$ and $D_{\mathrm{P}}$, UPGMA analyses. In the $S_{\mathrm{J}}$ analysis, cluster groups were defined at the $62 \% S$-level but clusters were recovered in the same order as in the $S_{\mathrm{SM}}$ analysis, with no change in composition. In the $D_{\mathrm{P}}$ analysis, clusters 1 and 2 and clusters 5 and 6 were closely related and there was a loose association between clusters 4 and 8 but, apart from this, the results corresponded to those obtained in the $S_{\mathrm{SM}}$ UPGMA analysis.

\section{Characterization of the clusters}

Table 2 lists the properties of the different clusters and identifies characters with potential diagnostic value. 


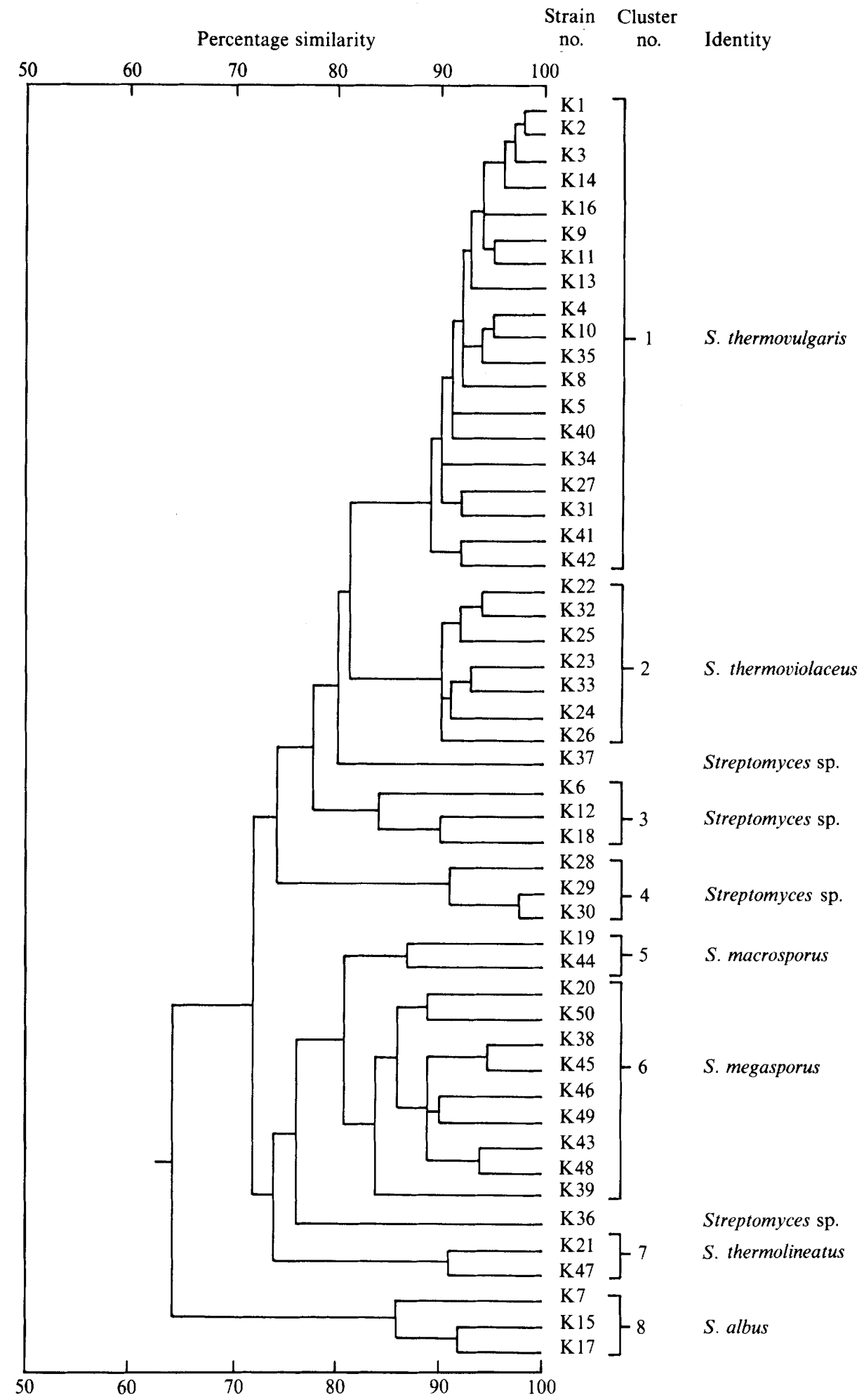

Fig. 1. Dendrogram showing the relationships between clusters recovered in the $S_{\mathrm{SM}}$, UPGMA analysis. 
Table 2. Distribution of positive characters to major, minor and single-member clusters defined at the $82 \%$ similarity level $\left(S_{\mathrm{SM}}\right)$

Values are the number of strains with positive character states. Character states which are most representative of and consistent within each major cluster are marked with an asterisk.

Major clusters

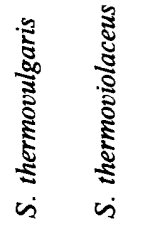

Minor clusters
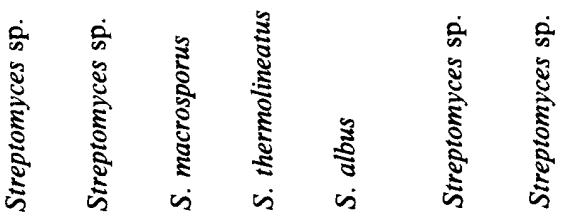

Cluster no.

No. of strains/strain no.

1
19

2

$\begin{array}{clll}0 & 0 & 0 & 3 \\ 3 & 0 & 1 & 0 \\ 16^{*} & 7^{*} & 8^{*} & 0\end{array}$

Rectiflexibiles

Retinaculiaperti

Spirales

Spore surface ornamentation:

Smooth

Warty

Spiny

Colour of aerial spore mass:

Red

Yellow

Grey

Green

Blue

White

$\begin{array}{clllllllll}19^{*} & 0 & 0 & 1 & 2 & 0 & 2 & 3 & 0 & 1 \\ 0 & 7^{*} & 9^{*} & 0 & 0 & 2^{*} & 0 & 0 & 1 & 0 \\ 0 & 0 & 0 & 2 & 1 & 0 & 0 & 0 & 0 & 0 \\ & & & & & & & & & \\ 0 & 2 & 0 & 0 & 0 & 0 & 0 & 0 & 0 & 0 \\ 0 & 0 & 5 & 1 & 0 & 0 & 0 & 0 & 0 & 0 \\ 18^{*} & 5 & 0 & 0 & 0 & 0 & 0 & 0 & 1 & 1 \\ 0 & 0 & 0 & 0 & 0 & 2 & 2 & 0 & 0 & 0 \\ 0 & 0 & 0 & 2 & 0 & 0 & 0 & 0 & 0 & 0 \\ 1 & 0 & 4 & 0 & 3 & 0 & 0 & 2 & 0 & 0\end{array}$

Pigmentation:

No distinctive substrate mycelial

pigments

Red/orange

Pigmentation of diffusible pigments:

Production of diffusible pigments

Red/orange

Yellow/brown

Blue

Sensitivity of substrate pigment to $\mathrm{pH}$

Sensitivity of diffusible pigment to $\mathrm{pH}$

Growth of sole nitrogen source $(0.1 \%, w / v)$ :

DL- $\alpha$-Amino-n-butyric acid

Potassium nitrate

L-Cysteine

L-Valine

L-Threonine

L-Serine

L-Phenylalanine

L-Methionine

L-Histidine

L-Arginine

L-Hydroxyproline

Enzyme activity:

Proteolysis on egg yolk

Lipolysis

Pectin hydrolysis

Nitrate reduction

Hydrogen sulphide production $\begin{array}{rlllllllll}19 & 1 & 9 & 3 & 3 & 2 & 2 & 3 & 0 & 1 \\ 0 & 6^{*} & 0 & 0 & 0 & 0 & 0 & 0 & 1 & 0\end{array}$

$\begin{array}{llllllllll}0 & 3 & 1 & 0 & 0 & 0 & 0 & 0 & 0 & 0 \\ 0 & 2 & 0 & 0 & 0 & 0 & 0 & 0 & 0 & 0 \\ 0 & 0 & 1 & 0 & 0 & 0 & 0 & 0 & 0 & 0 \\ 0 & 1 & 0 & 0 & 0 & 0 & 0 & 0 & 0 & 0 \\ 0 & 6 & 0 & 0 & 0 & 0 & 0 & 0 & 0 & 0 \\ 0 & 3 & 0 & 0 & 0 & 0 & 0 & 0 & 0 & 0\end{array}$


Table 2-continued

Major clusters

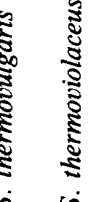

Minor clusters

Cluster no. . . . . . . . .

No. of strains/strain no.
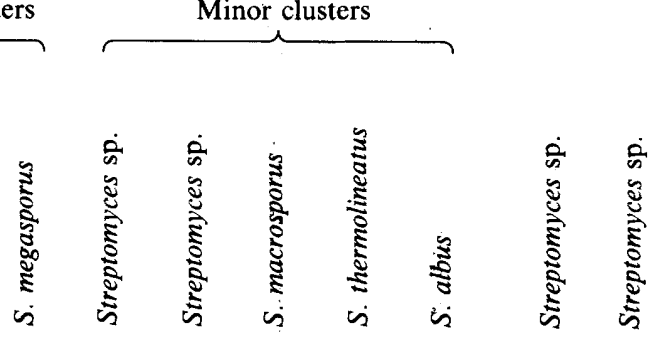

Degradation of:

Hippurate

Hypoxanthine

Elastin

L-Tyrosine

Adenine

DNA

RNA

Starch

Urea

Gelatin

Aesculin

Arbutin

Resistance to antibiotics $\left(\mu \mathrm{g} \mathrm{m}^{-1}\right) \dagger$ :

Tobramycin (50)

Rifampicin (50)

Cephaloridine (100)

Vancomycin (50)

Demethylchlortetracycline (500)

Oleandomycin (100)

Lincomycin (100)

Penicillin (10 i.u.)

Growth at :

$10 \%$

Growth in presence of $(\%, w / v)$ :

Sodium chloride (4)

Sodium chloride (7)

Sodium chloride (10)

Sodium chloride (13)

Sodium azide $(0.01)$

Sodium azide $(0.02)$

Phenyl ethanol $(0 \cdot 3)$

Phenol (0.1)

Potassium tellurite $(0.001)$

Potassium tellurite $(0.01)$

Thallous acetate $(0 \cdot 001)$

Thallous acetate $(0.01)$

Crystal violet (0.0001)

Growth on sole carbon sources $(0 \cdot 1 \%, w / v)$.

L-Arabinose

Sucrose

D-Xylose

meso-Inositol

Mannitol

D-Fructose

L-Rhamnose

Raffinose

D-Melezitose

$\begin{array}{rlllllllll}0 & 0 & 2 & 0 & 0 & 0 & 0 & 3 & 0 & 0 \\ 0 & 1 & 0 & 0 & 0 & 0 & 0 & 1 & 0 & 0 \\ 5 & 7 & 9 & 2 & 1 & 1 & 1 & 1 & 0 & 0 \\ 19 & 7 & 8 & 3 & 3 & 2 & 1 & 2 & 0 & 0 \\ 0 & 7 & 0 & 0 & 0 & 0 & 0 & 0 & 0 & 0 \\ 19 & 7 & 9 & 3 & 0 & 2 & 0 & 2 & 1 & 1 \\ 19 & 7 & 9 & 2 & 0 & 2 & 0 & 2 & 1 & 1 \\ 19 & 7 & 9 & 3 & 0 & 2 & 2 & 0 & 0 & 0 \\ 1 & 0 & 0 & 0 & 0 & 0 & 0 & 3 & 0 & 0 \\ 19 & 7 & 9 & 3 & 1 & 2 & 2 & 0 & 1 & 1 \\ 9 & 7 & 9 & 3 & 0 & 2 & 0 & 0 & 0 & 1 \\ 19 & 7 & 0^{*} & 3 & 0 & 2 & 0 & 3 & 0 & 1\end{array}$

$\begin{array}{rlllllllll}19 & 2 & 9 & 0 & 2 & 2 & 0 & 3 & 1 & 0 \\ 19 & 7 & 9 & 2 & 3 & 1 & 0 & 3 & 0 & 1 \\ 19 & 0^{*} & 8 & 3 & 3 & 2 & 2 & 3 & 1 & 1 \\ 12 & 0 & 0 & 3 & 0 & 0 & 0 & 2 & 0 & 0 \\ 0 & 0 & 0 & 0 & 2 & 0 & 0 & 3 & 0 & 0 \\ 16 & 0^{*} & 9 & 3 & 2 & 2 & 0 & 3 & 1 & 1 \\ 19 & 6 & 9 & 3 & 2 & 2 & 2 & 3 & 0 & 0 \\ 18 & 1 & 9 & 3 & 3 & 2 & 1 & 3 & 1 & 1\end{array}$

$\begin{array}{llllllllll}0 & 0 & 0 & 0 & 0 & 0 & 2 & 0 & 0 & 1\end{array}$

$\begin{array}{cccccccccc}19 & 5 & 5 & 0 & 0 & 0 & 0 & 3 & 1 & 1 \\ 0 & 0 & 0 & 0 & 0 & 0 & 0 & 3 & 0 & 0 \\ 0 & 0 & 0 & 0 & 0 & 0 & 0 & 2 & 0 & 0 \\ 0 & 0 & 0 & 0 & 0 & 0 & 0 & 2 & 0 & 0 \\ 19 & 7 & 9 & 1 & 1 & 1 & 2 & 3 & 1 & 1 \\ 19 & 7 & 9 & 1 & 1 & 0 & 0 & 3 & 0 & 1 \\ 19 & 2 & 9 & 0 & 0 & 2 & 0 & 0 & 1 & 1 \\ 19 & 7 & 9 & 2 & 1 & 2 & 1 & 1 & 0 & 1 \\ 19 & 7 & 9 & 3 & 1 & 2 & 1 & 3 & 0 & 1 \\ 19 * & 4 & 0 & 1 & 1 & 0 & 0 & 0 & 0 & 0 \\ 17 & 0 & 4 & 0 & 0 & 1 & 0 & 0 & 0 & 1 \\ 0 & 0 & 0 & 0 & 0 & 0 & 0 & 0 & 0 & 1 \\ 4 & 5 & 0 & 1 & 0 & 0 & 2 & 1 & 0 & 1\end{array}$

$\begin{array}{clllllllll}0 & 5 & 0 & 0 & 3 & 2 & 0 & 0 & 0 & 1 \\ 19 & 2 & 0 & 3 & 3 & 0 & 0 & 3 & 0 & 1 \\ 19 & 7 & 2 & 3 & 3 & 2 & 0 & 3 & 0 & 1 \\ 19 & 7 & 2 & 0 & 3 & 2 & 0 & 2 & 1 & 1 \\ 19 & 7 & 0^{*} & 1 & 3 & 0 & 1 & 3 & 0 & 1 \\ 19 & 7 & 0^{*} & 2 & 3 & 2 & 0 & 3 & 0 & 1 \\ 0 & 0 & 4 & 3 & 3 & 2 & 0 & 0 & 0 & 1 \\ 0 & 0 & 0 & 0 & 0 & 0 & 0 & 0 & 1 & 0 \\ 17^{*} & 0 & 0 & 1 & 3 & 0 & 0 & 2 & 0 & 0\end{array}$


Table 2-continued

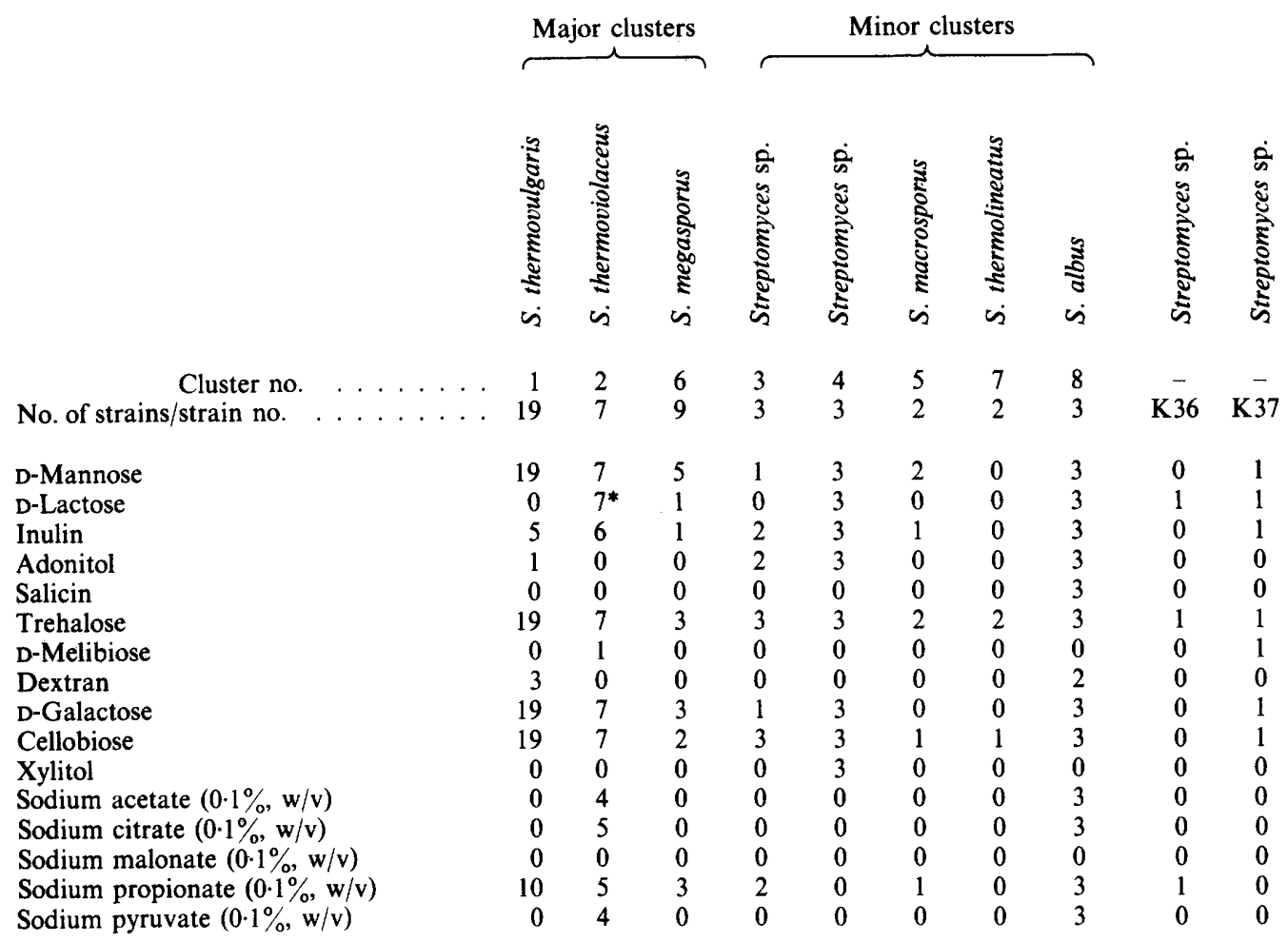

$\dagger$ Strains were tested for their ability to grow in the presence of freeze-dried filter paper discs previously soaked in antibiotic at the concentration shown (Goodfellow \& Orchard, 1974)

All of the strains produced spores in an aerial spore mass, degraded Tween 80 and casein, were resistant to gentamicin $\left(100 \mu \mathrm{g} \mathrm{ml}^{-1}\right)$, neomycin $\left(50 \mu \mathrm{g} \mathrm{ml}^{-1}\right)$ and streptomycin $(100 \mu \mathrm{g}$ $\left.\mathrm{ml}^{-1}\right)$, and grew at $37^{\circ} \mathrm{C}$ and $45^{\circ} \mathrm{C}$ and in the presence of phenyl ethanol $(0.1 \%, \mathrm{v} / \mathrm{v})$.

None of the strains produced verticillate spore chains, hairy or rugose ornamented spores, a violet aerial spore mass, green, blue or violet coloured substrate mycelium, green or violet diffusible pigments, or melanin pigments on either peptone yeast iron or tyrosine agars, and none showed fragmentation or spores on the substrate mycelium, produced sclerotia, exhibited antimicrobial activity against Pseudomonas fluorescens NCIB 9046, showed lecithinase activity on egg yolk, degraded chitin, guanine, xanthine, testosterone or allantoin, or grew either at $4{ }^{\circ} \mathrm{C}$ or at $\mathrm{pH} 4 \cdot 3$.

\section{Morphology}

Morphological observations are summarized in Tables 2 and 3. Strains in clusters 3 and 4 (Streptomyces spp.) grew insufficiently well for detailed morphological observations to be made. Organisms assigned to clusters 1 ( $S$. thermovulgaris) and 2 ( $S$. thermoviolaceus), and to the two single-member clusters, all had spore masses in the grey colour series, but the spore chains of the cluster 1 strains often became hygroscopic perhaps through autolysis, collapsing onto the agar and becoming dark brown to black. Strains in clusters 5 ('S. macrosporus'), 6 (S. megasporus) and 7 (Streptomyces $\mathrm{sp}$.) all produced green spore masses but sometimes in cluster 6 spores were close to tab $24 \frac{1}{2} \mathrm{dc}$ in the yellow colour series, perhaps when sporulation was poor. The spore masses of cluster 8 strains ( $S$. albus) were white following incubation at $25^{\circ} \mathrm{C}$ but became pink during incubation at $40^{\circ} \mathrm{C}$. Tight knotted spiral spore chains were characteristic of several clusters $(5$, $6,8, \mathrm{~K} 36, \mathrm{~K} 37$; Fig. $4 a$ ) while the spiral spore chains of the $S$. thermoviolaceus and $S$. 
Table 3. Summary of the morphological characteristics of thermophilic streptomycetes assigned to the different clusters

\begin{tabular}{|c|c|c|c|c|c|}
\hline \multirow[b]{2}{*}{ Cluster } & \multirow{2}{*}{$\begin{array}{l}\text { Spore colour } \\
\text { series* }\end{array}$} & \multirow{2}{*}{$\begin{array}{l}\text { Spore chain } \\
\text { morphology }\end{array}$} & \multirow{2}{*}{$\begin{array}{l}\text { Spore } \\
\text { surface }\end{array}$} & \multicolumn{2}{|c|}{ Spore size $(\mu \mathrm{m})$} \\
\hline & & & & Range & Mean \\
\hline S. thermovulgaris & $\begin{array}{c}\text { Grey } \\
3 \mathrm{li}-5 \mathrm{ih}\end{array}$ & $\begin{array}{c}\text { Spirals } \\
<3 \text { turns } \\
10-30 \text { spores }\end{array}$ & Smooth & $0.8-1.5 \times 0.6-1.0$ & $0.97 \times 0.79$ \\
\hline 2. S. thermoviolaceus & $\begin{array}{l}\text { Grey } \\
\mathrm{d}-4 \text { ig }\end{array}$ & $\begin{array}{c}\text { Spirals } \\
<2 \text { turns } \\
<10-30 \text { spores }\end{array}$ & Warty & $0.7-1.4 \times 0.5-0.9$ & $0.95 \times 0.67$ \\
\hline 5. S. macrosporus & $\begin{array}{l}\text { Green } \\
24 \text { ih }\end{array}$ & $\begin{array}{l}\text { Spirals } \\
<6 \text { turns } \\
<50 \text { spores }\end{array}$ & $\begin{array}{c}\text { Wrinkled } \\
\text { by SEM; } \\
\text { warty by } \\
\text { TEM }\end{array}$ & $0.7-1.8 \times 0.7-1.6$ & $1.12 \times 0.96$ \\
\hline 6. S. megasporus & 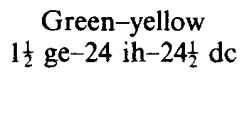 & $\begin{array}{l}\text { Spirals } \\
<6 \text { turns } \\
<30 \text { spores }\end{array}$ & $\begin{array}{c}\text { Wrinkled } \\
\text { by SEM; } \\
\text { warty by } \\
\text { TEM }\end{array}$ & $0.8-1.8 \times 0.5-1.2$ & $1.11 \times 0.77$ \\
\hline 7. S. thermolineatus & $\begin{array}{c}\text { Green } \\
24 \text { ih- } 24 \frac{1}{2} \text { ih }\end{array}$ & $\begin{array}{c}\text { Straight } \\
<30 \text { spores }\end{array}$ & Smooth & $1 \cdot 0-2.1 \times 0.9-1 \cdot 3$ & $1.43 \times 1.06$ \\
\hline 8. S. albus & $\begin{array}{l}\text { White-red } \\
3 \mathrm{ca}-5 \mathrm{ca}\end{array}$ & $\begin{array}{c}\text { Spirals } \\
<4 \text { turns } \\
10-50 \text { spores }\end{array}$ & Smooth & $0.6-1.0 \times 0.3-0.6$ & $0.78 \times 0.48$ \\
\hline Streptomyces sp. K36 & $\begin{array}{c}\text { Grey } \\
2 \mathrm{dc}-5 \mathrm{fe}\end{array}$ & $\begin{array}{c}\text { Spirals } \\
<4 \text { turns } \\
<10-30 \text { spores }\end{array}$ & Warty & $0.8-1.8 \times 0.5-1.0$ & $1.23 \times 0.73$ \\
\hline Streptomyces sp. K37 & $\begin{array}{c}\text { Grey } \\
2 \mathrm{fc}-3 \mathrm{fc}\end{array}$ & $\begin{array}{c}\text { Spirals } \\
3-4 \text { turns } \\
10-30 \text { spores }\end{array}$ & Smooth & $0.6-1.7 \times 0.6-1.0$ & $i .05 \times 0.75$ \\
\hline
\end{tabular}

* Spore mass colour series after Tresner \& Backus (1963).

thermovulgaris strains were often imperfectly formed, appearing straight, hooked or looped (Fig. $2 a, b)$. Spore chains in cluster 7 were straight (Fig. $5 a$ ).

The spores of $S$. thermovulgaris strains were smooth but those of $S$. thermoviolaceus strains were characteristically covered by small hemispherical warts $30-70 \mathrm{~nm}$ in diameter (Fig. $2 c$ ), as were spores of isolate K36. Spores of the 'S. macrosporus' and $S$. megasporus strains also resembled one another closely, appearing to have pronounced warts by transmission electron microscopy (Fig. $4 b$ ) but with irregular ridges and warts by scanning electron microscopy (Fig. 3 ). Spores of the remaining strains were smooth but those of the duplicate cultures in cluster 7 ( $S$. thermolineatus) were unusual in shape, the ends of the spores being long, and projecting from the oval spore body (Fig. $5 b$ ). The ends retained their shape when the rest of the spore collapsed under vacuum to give a phalangiform appearance in both transmission and scanning electron microscopy (Tresner et al., 1966). Only $S$. albus isolates formed spore chains at $25^{\circ} \mathrm{C}$ and these were generaily similar to those at $40^{\circ} \mathrm{C}$.

\section{DISCUSSION}

Our findings extend those of Williams et al. (1983), who found that the type strains of ' $S$. thermoflavus', $S$. thermonitrificans and $S$. thermovulgaris, incubated at $45^{\circ} \mathrm{C}$, formed a single cluster. In our three analyses, the thermophilic streptomycetes were recovered in an aggregate cluster distinct from the aggregate clusters formed by mesophilic streptomycetes. Of especial interest, in the $S_{\mathrm{SM}}$ classification, were the two adjoining and closely related clusters in the thermophilic streptomycete aggregate taxon formed by $S$. albus isolates. Our cluster 8 contained isolates examined at $45^{\circ} \mathrm{C}$ and cluster 16 of Williams et al. (1983) those, including the type strain, incubated at $25^{\circ} \mathrm{C}$. By contrast, the type strains of $S$. thermodiastaticus, 'S. thermophilus', 

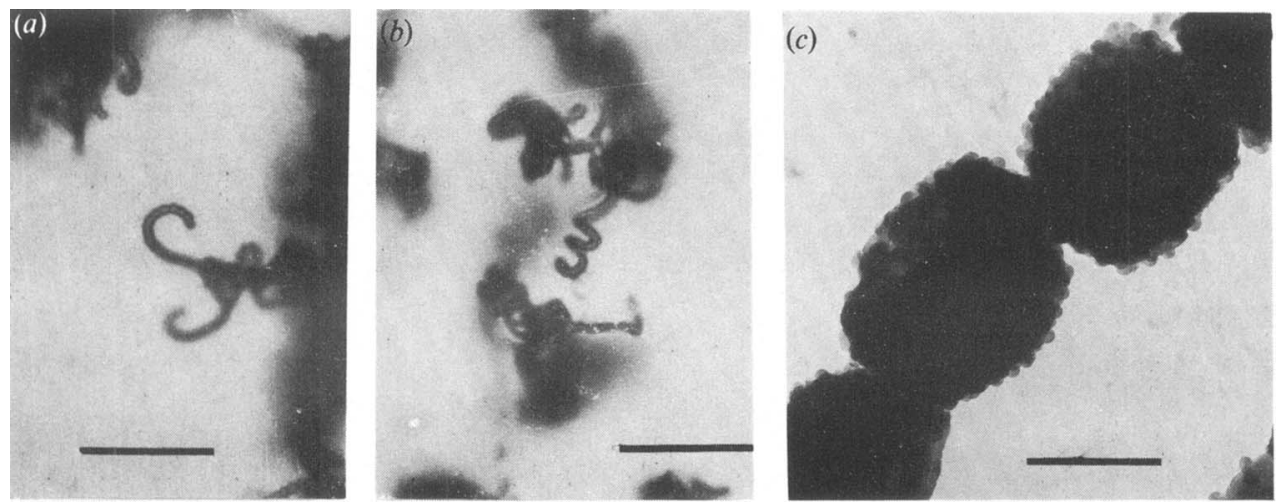

Fig. 2. (a,b) S. thermoviolaceus K23, spore chains. Bars, $20 \mu \mathrm{m}$. (c) S. thermoviolaceus $\mathrm{K} 24$, transmission electron micrograph of spores. Bar, $1 \mu \mathrm{m}$.

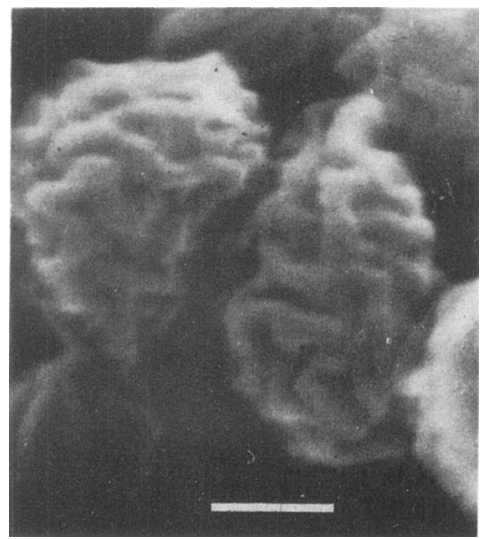

Fig. 3. S. macrosporus K19, scanning electron micrograph of spores. Bar, $0.5 \mu \mathrm{m}$.

'S. thermotolerans' and S. thermoviolaceus were recovered by Williams et al. (1983) at the periphery of numerically defined clusters containing mesophilic streptomycetes. This can be attributed to incubation of these strains at $25^{\circ} \mathrm{C}$, when conditions may barely have allowed growth, and to test and sampling error (Sneath \& Johnson, 1972; Austin \& Colwell, 1977). In the present study, $S$. thermoviolaceus marker strains were studied at $45^{\circ} \mathrm{C}$ and recovered in cluster 2 . The present findings strongly suggest that thermophilic streptomycetes are not merely variants of established mesophilic taxa, but further comparative work is required to determine the effect of cultivating strains at different temperatures, and especially near the limits for growth, on the stability of numerical taxonomies. However, the examination of actinobacteria at two different temperatures only marginally affected their position in the subsequent numerical classification (Goodfellow et al., 1985).

The thermophilic streptomycetes contrasted with the mesophilic strains in that none produced melanin pigments, they seldom exhibited activity against allantoin, chitin, guanine, hypoxanthine, testosterone, urea and xanthine, and all failed to grow in the presence of $7 \%(\mathrm{w} / \mathrm{v})$ $\mathrm{NaCl}$. Also, few thermophilic strains grew at $10^{\circ} \mathrm{C}$ or used compounds such as D-melibiose, raffinose, salicin and xylitol as sole carbon sources.

The numerical classification was unaffected by the coefficients used $\left(S_{\mathrm{SM}}, S_{\mathrm{J}}, D_{\mathrm{P}}\right)$ and several properties could be weighted to enable recognition of the three major clusters. It is evident that 

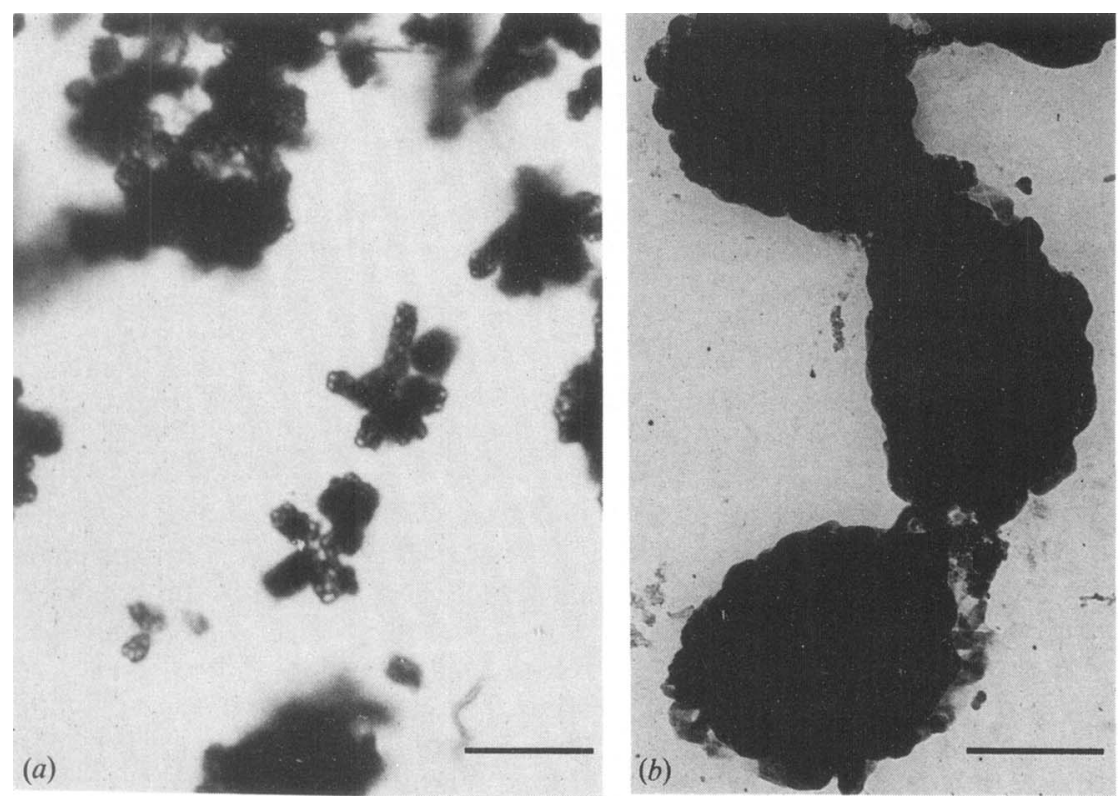

Fig. 4. (a) S. megasporus K43, spore chains. Bar, $20 \mu \mathrm{m}$. (b) $S$. megasporus K39, transmission electron micrograph of spores. Bar, $0.5 \mu \mathrm{m}$.
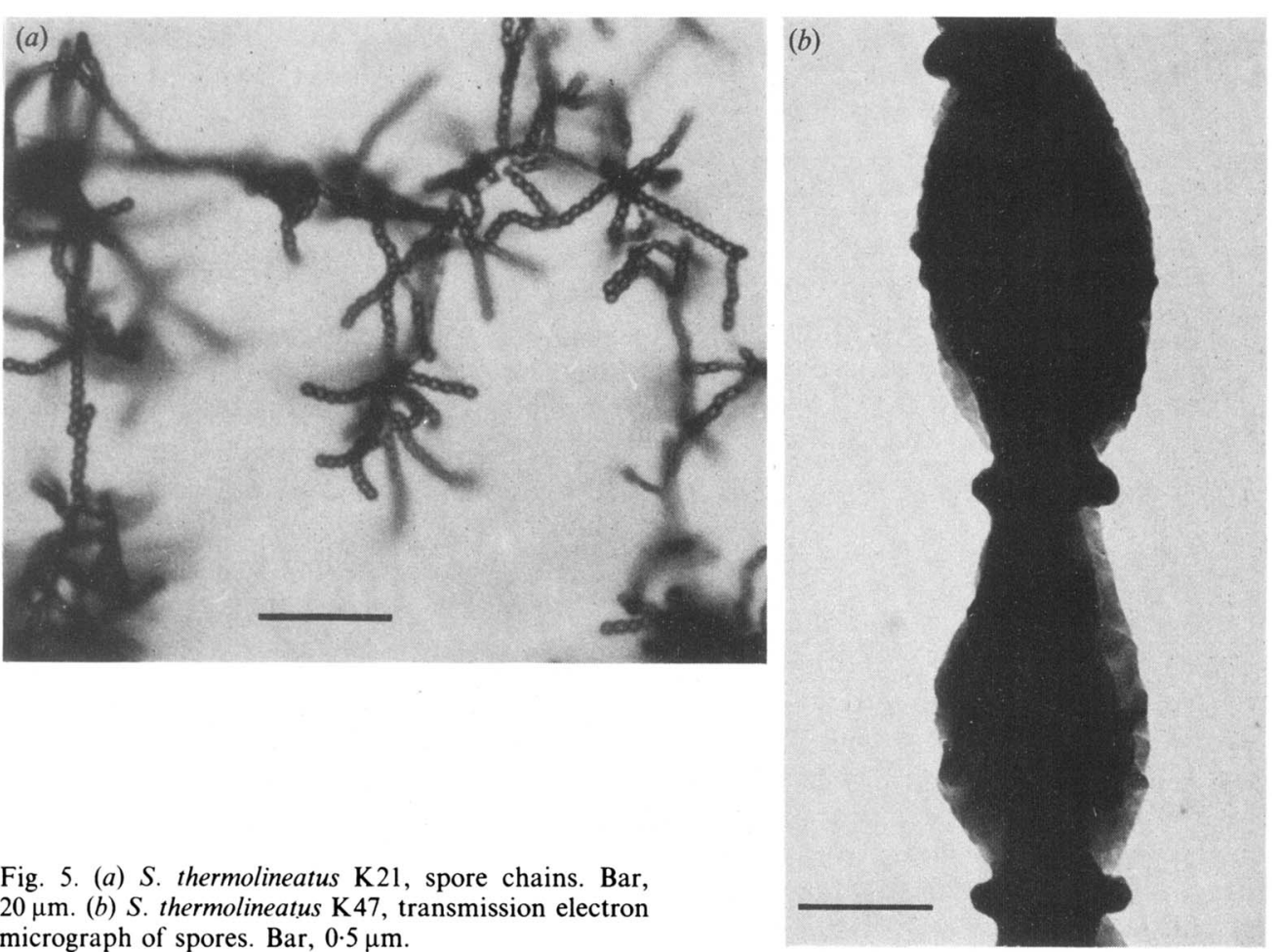

5. (a) $S$. thermolineatus K21, spore chains. Bar, $20 \mu \mathrm{m}$. (b) $S$. thermolineatus K47, transmission electron micrograph of spores. Bar, $0.5 \mu \mathrm{m}$. 
S. thermoviolaceus Henssen 1957 and $S$. thermovulgaris Henssen 1957 are good taxospecies and that $S$. thermonitrificans Desai \& Dhala 1967 and 'S. thermoflavus' (Kudrina \& Maksimova, 1963) Pridham 1970 fall within the boundaries of the former. Indeed, Desai \& Dhala (1967) only separated $S$. thermonitrificans and $S$. thermoviolaceus by a few biochemical and physiological properties that would now be considered insufficient for speciation (Williams et al., 1983). The recovery of $S$. thermonitrificans ISP 5579 and $S$. thermovulgaris ISP 5444 in a single cluster in the study of Williams et al. (1983) can be attributed to the small number of thermophilic streptomycetes examined and to the fact that single marker strains are seldom good representatives of species (Wilkinson \& Jones, 1977; Goodfellow et al., 1982).

Further comparative studies are required to establish the taxonomic affinities of $S$. thermodiastaticus ISP 5573, which was not included in this study. This organism was classified in a cluster (Cluster 1C; Streptomyces halstedii; Williams et al., 1983) shown to be heterogeneous on the basis of DNA : DNA pairing data (Mordarski et al., 1986). S. thermodiastaticus (Bergey et al., 1923) Waksman 1953 has many properties in common with $S$. thermoviolaceus Henssen 1957, including the ability to form spores with small hemispherical warts, in hooked and spiral chains. If synonymous with $S$. thermoviolaceus the epithet thermodiastaticus would have priority.

The third major phenon, cluster 6, can similarly be said to form a good taxospecies. This cluster corresponds to $S$. megasporus (Krassilnikov et al., 1968) Agre 1983 as it contains the type of this species. On the same basis, minor cluster 5 corresponds to 'S. macrosporus' Krassilnikov et al. 1986. Cluster 8, as shown earlier, corresponds to $S$. albus (Rossi-Doria, 1891) Waksman \& Henrici 1943. Cluster 7 is a distinctive new species for which the name Streptomyces thermolineatus is proposed. The remaining minor phena may form nuclei of previously undescribed species, but additional isolates and further work are needed to establish this.

Description of Streptomyces macrosporus (ex Krassilnikov et al., 1968, 66) nom. rev. sp. nov.

Ma.cro.spor'us. Gr. adj. makros long, large; Gr. n. spora seed; M.L. adj. macrosporus largespored.

Growth at $40{ }^{\circ} \mathrm{C}$ on half-strength nutrient and V-8 juice agars good; aerial mycelium in the green colour series near 24 ih (Tresner \& Backus, 1963), with white flecks, although may be thin and white on half-strength nutrient agar. At $25^{\circ} \mathrm{C}$, small colonies only, sometimes with sparse white aerial mycelium. Substrate mycelium colourless to dark brown with no distinctive pigments but often crystalline deposits in the agar. Melanoid pigments not produced on peptone iron agar. No soluble pigments.

Spores mostly in tight spirals of up to six turns and 50 spores but sometimes in short straight chains of only five spores. Spores appear warty in transmission electron micrographs but are characteristically wrinkled in scanning electron micrographs, $0.7-1.8 \times 0.7-1.6 \mu \mathrm{m}$, sometimes broader than long, mean $1.12 \times 0.96 \mu \mathrm{m}$ (Fig. 3).

Degrades aesculin, arbutin, casein, DNA, gelatin, RNA, starch and L-tyrosine; utilizes Dfructose, meso-inositol, D-mannose, L-rhamnose, trehalose and D-xylose as sole carbon sources, and L-arginine, L-phenylalanine, potassium nitrate and L-threonine as sole nitrogen sources. Proteolysis and lipolysis evident on egg yolk agar; pectin hydrolysed; hydrogen sulphide produced but nitrate not reduced.

Isolated from sewage compost and soil.

Type culture: DSM $41449=\mathrm{K} 44=\mathrm{A} 1201=$ INMI 2892.

Description of Streptomyces megasporus (ex Krassilnikov et al. 1968, 66) Agre 1983, VP emend.

Me.ga.spor'us. Gr. adj. megas big; Gr. n. spora seed; M.L. adj. megasporus big-spored.

Growth at $40^{\circ} \mathrm{C}$ on half-strength nutrient and V-8 juice agars good; aerial mycelium in the green colour series, between $1 \frac{1}{2}$ ge and 24 ih or sometimes in the yellow series near $24 \frac{1}{2} \mathrm{dc}$. Growth at $25^{\circ} \mathrm{C}$ poor, colourless and slimy in appearance with little or no aerial mycelium. Substrate mycelium colourless to olive grey on nutrient agar or dark brown on V-8 juice agar, no distinctive pigments. Yellow-brown soluble pigment sometimes produced; no melanoid pigment on peptone iron agar. 
Spore chains up to 30 spores long in tight spirals of up to six turns, although frequently only one or two turns (Fig. $4 a$ ). Spores appear warty in transmission electron micrographs, and with irregular warts and ridges in scanning electron micrographs, $0.8-1.8 \times 0.5-1.2 \mu \mathrm{m}$, mean $1.11 \times$ $0.77 \mu \mathrm{m}$ (Fig. $4 b$ ).

Degrades aesculin, casein, DNA, elastin, gelatin, RNA, starch and L-tyrosine; few isolates used any of the sole carbon and sole nitrogen sources tested but all caused proteolysis and lipolysis of egg yolk and produced hydrogen sulphide while none reduced nitrate to nitrite.

Isolated from air over a hayfield and in a cotton mill, from soil, mushroom compost and sewage compost.

Type culture: DSM $41450=\mathrm{K} 45=\mathrm{A} 1202=$ Agre 1869.

Description of Streptomyces thermolineatus Goodfellow, Lacey \& Todd sp. nov

Ther.mo.line.a'ta. Gr. f. $\mathrm{n}$. therme $\bar{e}$ heat; L. adj. lineatus, of a line, rectilinear. L. f. $\mathbf{n}$. thermolineata heat(-loving), linear (referring to spore chains).

Good growth at $40^{\circ} \mathrm{C}$ on V-8 juice agar, producing abundant aerial mycelium in the green colour series, 24 ih to $24 \frac{1}{2}$ ih. Colony reverse yellow-brown with no distinctive pigments. No melanoid pigment produced on peptone iron agar.

Spores in straight or flexuous chains less than 30 spores long (Fig. $5 a$ ). Spores smooth but ends often prolonged, projecting from the oval spore body and retaining their shape under vacuum when the rest of the spore collapses, to give a phalangiform appearance (Fig. $5 b$; Tresner $e t$ al., 1966). Spores measure $1.0-2.1 \times 0.9-1.3 \mu \mathrm{m}$, mean $1.43 \times 1.06 \mu \mathrm{m}$.

Degrades casein, gelatin and starch, uses trehalose and sometimes cellobiose and mannitol as sole carbon sources, and L-arginine, L-histidine, L-hydroxyproline, L-methionine, L-phenylalanine, potassium nitrate, $\mathrm{L}$-serine and L-valine as sole nitrogen sources. Reduces nitrate to nitrite and sometimes shows lipolytic and proteolytic activity on egg yolk.

Isolated from sewage compost.

Type culture: DSM $41451=\mathrm{K} 47=\mathrm{A} 1484$.

Description of Streptomyces thermoviolaceus Henssen 1957, $388^{\mathrm{AL}}$ emend.

Ther.mo.vi.o.la'ceus. Gr. f. n. thermē heat; L. adj. violaceus violet-coloured; M. L. adj. thermoviolaceus heat(-loving), violet-coloured (soluble pigment).

Synonyms: 'Streptomyces thermoflavus' (Kudrina \& Maksimova, 1963, 626) Pridham 1970, 27; Streptomyces thermonitrificans Desai \& Dhala 1967, 626.

Grows well at $40^{\circ} \mathrm{C}$ on V-8 juice, yeast/malt and glycerol/asparagine agars, producing plane or convolute colonies with aerial mycelium, but poorly on half-strength nutrient agar to give thin colourless colonies that often lack aerial mycelium. At $25^{\circ} \mathrm{C}$, growth is very restricted and colourless substrate mycelium only is produced. May grow also at $55^{\circ} \mathrm{C}$, producing thin colonies with little or no aerial mycelium. The sporulating aerial mycelium is various shades in the grey colour series (Tresner \& Backus, 1963), with white flecks. Substrate mycelium colourless, yellow or dark brown, sometimes modified by yellow or purple soluble pigment, the latter $\mathrm{pH}$-sensitive, turning red with acid. Melanoid pigments not produced on peptone iron agar.

Spore chains in open hooks or short spirals of up to two turns, usually fewer than 10 spores but occasionally up to 30 (Fig. $2 a, b$ ). Spores oval, $0.7-1.4 \times 0.5-0.9 \mu \mathrm{m}$, mean $0.95 \times 0.67 \mu \mathrm{m}$, characteristically with small hemispherical warts, about $30-70 \mathrm{~nm}$ diameter, covering the surface (Fig. $2 c$ ) but sometimes appearing smooth.

Degrades adenine, aesculin, arbutin, casein, DNA, elastin, gelatin, RNA, starch and Ltyrosine; uses cellobiose, D-fructose, D-galactose, meso-inositol, D-lactose, mannitol, mannose, trehalose and xylose as sole carbon sources, and DL- $\alpha$-amino-n-butyric acid, L-arginine, Lcysteine, L-histidine, L-methionine, L-phenylalanine, potassium nitrate, L-serine, L-threonine and $\mathrm{L}$-valine as sole nitrogen sources. Proteolysis and lipolysis evident on egg yolk, hydrogen sulphide produced, but nitrate not reduced.

Isolated from soil dung and from moulding hay, cereal grains and sugar-cane bagasse.

Type culture: ATCC 19283. 
Description of Streptomyces thermovulgaris Henssen 1957, 391 ${ }^{\mathrm{AL}}$ emend.

Ther.mo.vul.ga'ris. Gr. f. n. thermē heat; L. adj. vulgaris common; M.L. adj. thermovulgaris heat(-loving), common.

Growth moderate to good at $40{ }^{\circ} \mathrm{C}$ on half-strength nutrient and V-8 juice agars and often also on yeast/malt and glycerol/asparagine agars although sometimes with sparse aerial mycelium only. At $25^{\circ} \mathrm{C}$ little or no growth, without aerial mycelium. Sporulating aerial mycelium in the grey colour series corresponding to tabs 3 li to 3 ig or 5 ih unless aerial mycelium is sparse, when only d to dc (Tresner \& Backus, 1963). Aerial mycelium often becoming hygroscopic, collapsing onto the agar to form dark brown to black areas. Colony reverse colourless to dark brown with no distinctive pigments. Melanoid pigments not produced on peptone iron agar. No soluble pigments.

Spores produced in straight, hooked and spiral chains with up to three turns, less than $10-50$ spores long. Spores globose to oval, smooth or slightly roughened, $0.8-1.5 \times 0.6-1.0 \mu \mathrm{m}$, mean $0.97 \times 0.79 \mu \mathrm{m}$.

Degrades arbutin, casein, DNA, gelatin, RNA, starch and L-tyrosine; utilises cellobiose, Dfructose, D-galactose, meso-inositol, mannitol, D-mannose, sucrose, trehalose and D-xylose as sole carbon sources, and L-arginine, L-histidine, L-methionine, L-phenylalanine, L-serine, Lthreonine and L-valine as sole nitrogen sources. Proteolysis and lipolysis evident on egg yolk; hydrogen sulphide produced, and nitrate reduced.

Isolated from fresh and rotted faeces of cows, sheep and horses, garden and mushroom composts, sugar-cane bagasse, cocoa beans and coffee dust.

Type culture: ATCC $19284=\mathrm{K} 27$.

The present study provides further evidence that thermophilic streptomycetes are widely distributed in nature, particularly in compost heaps and decaying vegetable matter where temperatures of at least $65^{\circ} \mathrm{C}$ occur (Henssen, 1957; Lacey, 1973). The improved classification of these organisms should facilitate ecological studies in substrates such as fodders and composts.

The authors are greatly indebted to Dr A. Seino for the gift of cultures and to Mrs S. Roberts for assistance with electron microscopy.

\section{REFERENCES}

AGRE, N. S. (1983). In $A$ Guide for the Determination of Actinomycetes. Genera Streptomyces, Streptoverticillium and Chainia, p. 52, p. 71 . Edited by T. F. Gause, T. P. Preobrazhenskaya, M. A. Sveshnikova, L. P. Terekhova \& T. S. Maksimova. Moscow: Nauka (in Russian).

AGre, N. S. (1986). In Validation of the publication of new names and new combinations previously effectively published outside the IJSB. List no. 22. International Journal of Systematic Bacteriology 36, 573-576.

Austin, B. \& Colwell, R. R. (1977). Evaluation of some coefficients for use in numerical taxonomy of micro-organisms. International Journal of Systematic Bacteriology 27, 204-210.

Bergey, D. H. Harrison, F. C., Breed, R. S., Hammer, B. W. \& Huntoon, F. M. (1923). Bergey's Manual of Determinative Bacteriology, 1st Edn. Baltimore: Williams \& Wilkins.

Corbaz, R., Gregory, P. H. \& LACEy, M. E. (1963). Thermophilic and mesophilic actinomycetes in mouldy hay. Journal of General Microbiology 32, 449456.

Craveri, R. \& Pagani, H. (1962). Thermophilic micro-organisms among actinomycetes in the soil Annali di microbiologia 12, 115-130.
Desai, A. J. \& Dhala, S. A. (1967). Streptomyces thermonitrificans sp. n., a thermophilic streptomycete. Antonie van Leeuwenhoek 33, 137-144.

GILBERT, R. (1904). Ueber Actinomyces thermophilus und andere Actinomyceten. Zeitschrift für Hygiene und Infektionskrankeiten 47, 383-406.

GoOdFellow, M. \& ORChARD, V. A. (1974). Antibiotic sensitivity of some nocardioform bacteria and its value as a criterion for taxonomy. Journal of General Microbiology 83, 375-387.

Goodfellow, M., Weaver, C. R. \& Minnikin, D. E. (1982). Numerical classification of some rhodococci, corynebacteria and related organisms. Journal of General Microbiology 128, 731-745.

Goodfellow, M., Embley, T. M.\& Austin, B. (1985). Numerical taxonomy and emended description of Renibacterium salmoninarum. Journal of General Microbiology 131, 2739-2752.

Gregory, P. H. \& LACEY, M. E. (1963). Mycological examination of dust from mouldy hay associated with farmer's lung disease. Journal of General Microbiology 30, 75-88.

Henssen, A. (1957). Über die Bedeutung der thermophilen Mikroorganismen für der Zersetzung des Stallmistes. Archiv für Mikrobiologie 27, 63-81.

JONES, K. L. (1949). Fresh isolates of actinomycetes in 
which the presence of sporogenous aerial mycelia is a fluctuating characteristic. Journal of Bacteriology 57 , 141-145.

Krassilnikov, N. A., Agre, N. S., Dorokhova, L. A. \& Sokolov, A. A. (1968). Three new species of thermophilic actinomycetes. Mikrobiologiya 37, 7583 (in Russian).

Kundrina, E. S. \& Maksimova, T. S. (1963). Some species of thermophilic Actinomyces from soils of China and their antibiotic properties. Mikrobiologiva 32, 623-631 (in Russian).

KÜSTER, E. \& LoCCI, R. (1963). Studies on peat and peat micro-organisms. I. Taxonomic studies on thermophilic actinomycetes isolated from peat. Archiv für Mikrobiologie 45, 188-197.

KÜster, E. \& WilliaMs, S. T. (1964). Selection of media for isolation of streptomycetes. Nature, London 202, 928-929.

KUTZNER, H. J. (1981). Streptomycetaceae. In The Prokaryotes: a Handbook of Habitats, Isolation and Identification of Bacteria, pp. 2028-2090. Edited by M. P. Starr, H. Stolp, H. G. Trüper, A. Balows \& H. G. Schlegel. Berlin: Springer Verlag.

LACEY, J. (1973). Actinomycetes in soils, composts and fodders. In Actinomycetales: Characteristics and Practical Importance pp. 231-251. Edited by F. A. Skinner \& G. Sykes. London: Academic Press.

LACEY, J. (1975). Airborne spores in pastures. Transactions of the British Mycological Society 64, 265-281.

LACEY, J. \& DUTKIEWICZ, J. (1976). Methods of examining the microflora of mouldy hay. Journal of Applied Bacteriology 41, 13-27.

LACEY, J. \& LACEY, M. E. (1987). Micro-organisms in the air of cotton mills. Annals of Occupational Hygiene 31, 1-19.

Mordarski, M., Goodfellow, M., Williams, S. T. \& SNEATH, P. H. A. (1986). Evaluation of species groups in the genus Streptomyces. In Biological. Biochemical and Biomedical Aspects of Actinomycetes, pp. 517-525. Edited by G. Szabó, S. Biró \& M. Goodfellow. Budapest: Akadémiai Kiadó.

PridHAM, T. G. (1970). New names and new combinations in the order Actinomycetales Buchanan 1917. Technical Bulletin, Agricultural Research Service, United States Department of Agriculture no. 1424.

PridhaM, T. G. \& Tresner, H. D. (1974). Family VII. Streptomycetaceae Waksman and Henrici 1943, 339. In Bergey's Manual of Determinative Bacteriology, 8 th edn, pp. 747-748. Edited by R. E. Buchanan \& W. E. Gibbons. Baltimore: Williams \& Wilkins.

Rossi-Doria, T. (1891). Su di alcune specie di 'Streptothrix' trovate nell'aria studiate in rapporto a quelle giá note e specialmente all' 'Actinomyces'. Annali dell' Istituto d'igiene sperimentale, Università Roma 1, 399-438.

Shirling, E. B. \& Gottlieb, D. (1966). Methods for characterization of Streptomyces species. International Journal of Systematic Bacteriology 16, 313-340.
Skerman, V. B. D., McGowan, V. \& Sneath, P. H. A. (1980). Approved lists of bacterial names. International Journal of Systematic Bacteriology 30, 225-420.

SNEATH, P. H. A. (1957). The application of computers to taxonomy. Journal of General Microbiology 17, 201-226.

SNEATH, P. H. A. (1968). Vigour and pattern in taxonomy. Journal of General Microbiology 54, 1-11.

SNEATH, P. H. A. \& Johnson, R. (1972). The influence on numerical taxonomic similarities of errors in microbiological tests. Journal of General Microbiology 72, 377-392.

SNEATH, P. H. A. \& SoKal, R. R. (1973). Numerical Taxonomy. The Principles and Practice of Numerical Taxonomy. San Francisco: W. H. Freeman.

SOKAL, R. R. \& MiChENER, C. D. (1958). A statistical method for evaluating systematic relationships. Kansas University Science Bulletin 38, 1409-1438.

TResner, H. D. \& Backus, E. J. (1963). System of colour wheels for streptomycete taxonomy. Journal of Applied Microbiology 11, 335-338.

Tresner, H. D., Davies, M. C. \& Engbert, M. E. (1966). Morphological subtype of the smooth-spored streptomycetes. Journal of Bacteriology 91, 19982005.

W AKSMAN, S. A. (1953). In Guide to the Classification and Identification of the Actinomycetes and their Antibiotics. Edited by S. A. Waksman \& H. A. Lechevalier. Baltimore: Williams \& Wilkins.

Waksman, S. A. \& HenricI, A. T. (1943). The nomenclature and classification of actinomycetes. Journal of Bacteriology 46, 337-341.

Waksman, S. A. \& HenriCI, A. T. (1948). Family Actinomycetaceae Buchanan and Family Streptomycetaceae Waksman and Henrici. In Bergey's Manual of Determinative Bacteriology 6th edn, pp. 892-980. Edited by R. S. Breed, E. G. D. Murray \& A. P. Hitchens. Baltimore: Williams \& Wilkins.

Waksman, S. A., Umbreit, W. W. \& Cordon, T. C. (1939). Thermophilic actinomycetes and fungi in soils and in composts. Soil Science 47, 37-61.

Wellington, E. M. H. \& Williams, S. T. (1978). Preservation of actinomycete inoculum in frozen glycerol. Microbios Letters 6, 151-157.

WILkinson, B. J. \& JoNES, D. (1977). A numerical taxonomic survey of Listeria and related bacteria. Journal of General Microbiology 98, 399-421.

Williams, S. T., Goodfellow, M., Alderson, G., Wellington, E. M. H., Sneath, P. H. A. \& Sackin, M. J. (1983). Numerical classification of Streptomyces and related genera. Journal of General Microbiology 129, 1743-1813.

WishaRT, D. (1978). Clustan User Manual. Version 1C, Release 2, 3rd edn. Edinburgh: Edinburgh University Program Library Unit. 